\title{
Reporting Child Sexual Abuse within Religious Settings: Challenges and Future
} Directions

\author{
Craig A. Harper \\ Nottingham Trent University (UK
}

Colin Perkins

Church of England (UK) 


\begin{abstract}
The sexual abuse of children within religious settings is an issue that has gained increased popular and professional attention over the past two decades. Various reports have highlighted the scale of such abuse, along with shortcomings in reporting practices. In this article, we outline some contemporary research that sought to understand the psychology that underpins variable reporting practices. In line with this research, we set out two conceptual frameworks that have some potential to help to explain such practices: system justification theory and moral foundations theory. Further, we describe how these frameworks could be adopted in research moving forward in order to make sense of the ways in which members of religious groups respond to allegations of child sexual abuse within their institutions. We close the article by arguing that by gaining a deeper understanding of the psychology underlying reporting practices, it may be possible to communicate more effectively about child sexual abuse within religious institutions, and therefore encourage more widespread reporting of allegations before more children are harmed.
\end{abstract}

Keywords: clergy abuse, Church, religion, child sexual abuse, sexual offending 


\section{Key Practitioner Messages}

- Those most likely to observe or suspect child abuse in religious settings are themselves likely to participate in such settings.

- The challenge for these 'onlookers' is to overcome the psychological dynamics that push against the recognition and reporting of child abuse in religious settings.

- These dynamics can be understood via established psychological theories and frameworks.

- Practitioners concerned with improving reporting practice in these contexts can draw on this work to inform training and intervention strategies. 


\section{Reporting child sexual abuse within religious settings: Challenges and future directions}

The sexual abuse of children in institutions, a matter of public interest since at least the early 1990s, has in recent years become the focus of heightened concern in the national discourse. The abuse of children in religious settings, with the most well-known (but certainly not only) example being in the Roman Catholic Church throughout the world (see e.g. Keenan 2012), has contributed to an understandable public reaction: not just shock, but anger. This anger has been directed at both the perpetrators of this abuse and at those within the institutions who appear to have failed to 'read the signs' that abuse was occurring, or in some cases to have indeed read those signs and yet failed to act upon them.

Much of the associated media discourse has called for control-led and risk-based responses to the perceived failure to recognise, respond to or report child sexual abuse in institutions, replicating a common media response to this topic (e.g. Lonne \& Parton 2014). In particular, the theme of 'mandatory reporting' of alleged or suspected child abuse in institutions has, in some quarters, been taken up as a shibboleth of the commitment to eradicate such abuse in the future. According to a recent summary report of a roundtable event, hosted by the NSPCC (2014), mandatory reporting is defined as a process that places a legal duty on designated groups of people associated with institutions to report incidents of child abuse. Mandatory reporting is enshrined in law in the USA and Canada, and across much of Australia. The UK has precise statutory guidance, such as the UK government document 'Working Together' (HM Government 2015), which places a clear professional expectation (though not compulsion) on people to report suspected abuse, and the government has recently concluded a consultation exercise 
regarding the potential implementation of a mandatory reporting duty in England and Wales. However, we know that even in those jurisdictions where these laws are in place, reporting practices are often inconsistent (most recently popularised in the movie Spotlight, which dramatised the story of the cover-up, and subsequent reporting, of decades of child sexual abuse within the Archdiocese of Boston, part of the US Catholic Church; see also Reilly 2003). In this article, we outline some of the potential barriers to such reporting in religious settings, and identify some ways in which we might begin to test some methods that are designed to increase compliance with reporting standards.

\section{The scale of sexual abuse within religious settings}

While attempts have been made to quantify the prevalence of child sexual abuse (CSA) in the general population (see for instance the meta-analysis by Stoltenborgh et al. (2011), who described CSA as a "global problem of considerable extent": 90), data regarding institutional CSA is scarce and inconsistent (Keenan 2012). Much of the available research in this regard comes from analyses of the Roman Catholic Church, which, as a global organisation accountable to a single primary authority (Rome), is uniquely positioned to gather such data. Even then, data are emergingin an unstructured fashion, driven often by media reports and subsequent inquiries. Thus, while a comprehensive and definitive picture of the scale of institutional CSA is not currently available, and while much of our discussion will include references to the Roman Catholic Church, we would encourage readers to apply the examples presented in this section as illustrations of the potential scope of CSA in wider religious settings.

The most substantial study to date is the 'John Jay Report' (John Jay College 2004; 2006; Terry et al. 2011), which was commissioned by the U.S. Conference of Catholic 
Bishops as part of the response to public scandals. Scrutinizing files between 1950 and 2002 , it was reported that 10,667 children had been abused by 4,392 priests and deacons - representing $4 \%$ of the clergy who had served during this period. Further, Terry et al. (2011) reported that over 3000 additional victims had come forward since the publication of the 2004 report, although it was noted that the prevalence of abuse within the U.S. Catholic Church appears to have peaked in the mid-1980s, and had been gradually declining since then.

In 1996 the Catholic Archdiocese of Melbourne in Australia instituted 'The Melbourne Response', an initiative which, according to the Archdiocesan website, "assists people who have been abused sexually, physically or emotionally" within the Church. The independent commissioner handling reports for the Melbourne Response (Peter O'Callaghan QC) has publicly stated that he has found more than 300 confirmed cases of clergy-perpetrated CSA, in evidence submitted to the Protecting Victoria's Vulnerable Children Inquiry (Cummins et al. 2012). The subsequent report of the Victorian Parliament, 'Betrayal of Trust', received 'hundreds of accounts' from alleged victims of CSA in religious settings, and yet declined to suggest an overall figure regarding the scope of such abuse. It also acknowledged "those victims who were unable to participate in the Inquiry - who remained locked in silence, who found the re-telling of their experience too traumatic, or who have taken their lives" as a result of their abuse (Parliament of Victoria 2013: vi), indicating a belief that CSA in Australian religious contexts is substantially more widespread than the official estimates may suggest.

In May 2010, again in response to an increased public awareness of the sexual abuse of children, the German government set up a confidential telephone line for victims to report such abuse. In the first 18 months, 4,208 people contacted the service to report 
being sexually abused as children, 534 of which had been abused in Catholic or Protestant institutions (Spröber et al. 2014). Following a torrent of revelations regarding child abuse in the Catholic Church in the Republic of Ireland, the Commission of Investigation Report into the Catholic Archdiocese of Dublin (the 'Murphy Report') reported in 2009 that it had received information pertaining to alleged CSA against 172 named priests and 11 unnamed priests, and concluded that 102 of these priests came within the Commission's remit. The Commission examined complaints regarding the abuse of over 320 children, yet it acknowledged that the number of perpetrators or victims known to the Commission was unlikely to yield a sense of the true scale of abuse. Indeed, one accused priest admitted to the Commission that he had abused over 100 children, while another suggested that he had abused fortnightly for over 25 years. The Commission of Inquiry into Child Abuse in Ireland (the 'Ryan Report'; Ryan 2009), heard evidence from 1,090 adults who recounted being abused as children within a range of institutional settings. While the Ryan Report (unlike the Murphy Report) looked at all institutions in Ireland, it should be noted that this country'sspecific historical situation meant that many of those institutions within which abuse took place were inextricably linked to the Irish Catholic Church (e.g. McLoone-Richards 2012).

\section{Current practices in reporting sexual abuse in religious settings}

The failure to recognise child sexual abuse, and indeed the failure to report such abuse when it is either known about or suspected, has featured prominently in the numerous reports already available on the theme of sexual abuse in religious settings. The report of an investigation by the Attorney General of Massachusetts into CSA in the Catholic Archdiocese of Boston (Reilly 2003), which exposed a "massive and prolonged 
mistreatment of children by priests" (p.2), found that "throughout the decades that the Archdiocese was dealing with a large and growing problem of clergy sexual abuse of children, it steadfastly maintained a practice of not reporting allegations of sexual abuse of children to law enforcement" (p.52). A 2005 inquiry into child sexual abuse in the Irish Catholic Diocese of Ferns identified over 100 allegations of CSA against 21 priests between 1962 and 2002. Again, very poor reporting practices were identified (Murphy et al. 2005). The Murphy Report into the Archdiocese of Dublin found that "all...considerations, including the welfare of children and justice for victims, were subordinated' to the priorities of 'the maintenance of secrecy, the avoidance of scandal, the protection of the reputation of the Church, and the preservation of its assets" (Murphy et al. 2009: 4). Unsurprisingly, given this overarching finding, the reporting practices of the Archdiocese regarding CSA were characterised as “don't ask, don't tell” (p.9). The wider-ranging Commission to Inquire into Child Abuse (the aforementioned 'Ryan Report') noted that "cases of sexual abuse were managed with a view to minimising the risk of public disclosure and consequent damage to the institution and the Congregation. This policy resulted in the protection of the perpetrator" (p.21).

The Ryan Report noted that reporting practices of CSA in institutions in Ireland were not uniform, and that the willingness to report varied with the identity of the perpetrator:

"When lay people were discovered to have sexually abused, they were generally reported to the Gardai. When a member of the Congregation was found to be abusing, it was dealt with internally and not reported to the Gardai... The difference in treatment of lay and religious abusers points to an awareness on the part of 
Congregational authorities of the seriousness of the offence, yet there was a reluctance to confine religious [order members] who offended in this way." (Ryan 2009: 21).

This crucial detail - of differential reporting practices according to the role of the perpetrator - warrants further attention. While advocates of mandatory reporting suggest that such inconsistent practices can only be remedied by compelling the reporting of abuse, there is evidence to suggest that mandated reporters still exercise similar levels of discretion as do non-mandated actors (e.g. Levi et al. 2006; Smith 2010). This is in spite of possible sanctions that can be placed on organisations and individuals who do not comply with the legislation (e.g. fines of up to $\$ 10,000$ and/or imprisonment of up to 5 years in some States in the USA; Children's Bureau, 2016).

The various reports cited in this paper detail different types of 'failure' to report CSA, such as failure to recognise or believe that abuse is happening, and failure to report abuse even when it is recognised. However, there may be common psychological features that help us explicate these various phenomena. Brackenridge (2001), writing within the context of CSA in sport, uses a 'triangular model' of child protection drawn from the work of Helen Armstrong to explicate the response of the 'onlooker' who observes child abuse (whether or not that observation leads to suspicion). In reference to this model, Brackenridge asks a telling question: Who are these onlookers, and where do their allegiances lie? She notes that in a sport setting, the onlookers will likely be those who are committed to that setting (e.g. players, staff, supporters), and by extension are loyal to the institution within which the abuse occurs. Noting research which indeed shows that sports organisations find it difficult to sympathise with victims of sexual abuse, 
Brackenridge argues that this difficulty arises from the challenge any report of abuse presents to the viability of the institution. That is, taking a report of abuse seriously draws institutionally-connected onlookers "into recognising publicly that there are flaws in the very institution...that supports their own existence. It is far less problematic for onlookers to minimise or ignore problems of sexual exploitation, or to align with the alleged abusers, whether overtly or by default, since this enables life to continue much as before" (p.167).

In a recent experimental study of these effects in the context of religious institutional affiliation, Minto et al. (2016) examined the extent to which social identity (operationalized as religious identification) had an impact on churchgoers' propensities to believe an allegation of historical sexual abuse by a Catholic priest. The authors found that Christians (both of Catholic and non-Catholic denominations) were more likely to be sceptical about the allegation, rate the alleged victim as less credible, and rate the priest as more credible, than non-Christians (a mixed group which comprised of participants of non-Christian faiths, and of no faith at all). Further, and only among Catholics, these effects were mediated by religious identification, but were not moderated by ambiguity of guilt. That is, Catholics who identified strongly with their faith were more likely to be sceptical of the allegation (including finding the alleged victim as less credible and the priest as more credible) than those who identified with their faith to a lesser extent, but these responses were not tempered when evidence of certainty of the priests' guilty was presented. In their discussion, Minto et al. (2016) stated that these effects represent a motivated degradation of alleged victims of sexual abuse by members of the Catholic Church, and an attempt to bolster the sense of morality that the Church holds most dear.

Minto et al. (2016) noted that the trend towards disbelieving allegations of child abuse perpetrated by clergy was contrary to what may be expected. Ingroup behaviour 
tends towards the rapid exclusion of the deviant. Arguably in this case, this would be the suspected abusive priest. Discussing this phenomenon, Minto and her colleagues echo Breckinridge's thoughts regarding 'onlookers'; acknowledging the existence of the 'deviant priest' threatens the validity and integrity of the institution, and it is the institution through which the onlookers gain a sense of identity and purpose. It is far easier, therefore, to exclude the victim, whose report threatens the institution and therefore the institutionally-derived identity, than to deal with the report on its own terms (Minto et al. 2016).

These behaviors may not derive from deliberate, carefully-reasoned decisionmaking. Arguing from within the psychodynamic tradition, and noting the importance of the emotional content of institutional identification, Carr (2001) stated that "in becoming a member of a group or organization, the individual surrenders some of their identity ... [and views] their own identity in terms of their ... context" (pp.426-427). The processes involved in forming this merged relationship between personal and institutional selves which Carr terms narcissistic identification - are "deep-seated, largely unconscious, intimately connected to the development of identity, and have emotional content" (p.429). It may also be that in the context of religious institutions, strict adherence to doctrine and institutional standards further compounds this effect, contributing to a lesser propensity to believe allegations of child sexual abuse in such settings, as observed by Minto and colleagues. As the Church typically sees itself as a bastion of high moral standards, members may have a difficult time accepting that those at its helm are capable of perpetrating such acts (e.g. Scheper-Hughes \& Devine 2003).

\section{Understanding and addressing current reporting practices: Directions for research}


The descriptive conceptual explanations for a lack of recognition or reporting of sexual abuse within institutions (e.g. Brackenridge 2001; Scheper-Hughes \& Devine 2003), coupled with the recent experimental data reported by Minto et al. (2016), suggest that enacting blanket mandatory reporting legislation may not be effective in improving reporting practices in religious settings. Mandatory reporting still requires people to believe that abuse may be happening; the discussion so far indicates that those most likely to observe the signs may be the least likely to believe them. Instead, a more indirect approach may be required. That is, methods to encourage reporting that are informed by psychological theories and frameworks potentially offer a more effective way of encouraging Brackenridge's (2001) 'onlookers' to recognise potential cases of child sexual abuse to relevant authorities. In this section, we first set out what these psychological frameworks look like, and outline how they can be used to theoretically explain under-reporting of CSA within religious setting. Next, we offer some testable hypotheses for examining their empirical validity in this area. Finally, we highlight some potential practical uses of these frameworks in order to improve current reporting practices in closed communities.

\section{System Justification Theory}

System justification theory (SJT; Jost et al. 2004) asserts that people are implicitly motivated to "justify and rationalise the way things are, so that existing social, economic, and political arrangements tend to be perceived as fair and legitimate" (Jost \& Hunyady 2005: 260). Previous research has found that the 'system justification motive' can contribute to judgements that may be at-odds with perceived wisdom, such as justifications for unequal pay among the genders (Jost \& Thompson 2000), the attribution 
of personality flaws to people who are medically unfit (Kay et al. 2007), and the belief that some level of income inequality is justifiable (as a result of living in a meritocratic society; Jost et al. 2003). Importantly, the system justification motive is typically exaggerated when people perceive a threat being posed to the status and legitimacy of the existing status quo. For example, Kay et al. (2005) reported a series of studies whereby participants' motivations for affirming the status quo was heightened by presenting a fictitious news story written by an outsider (depicted as a foreign journalist) that criticised the state of American society.

The system justification motive appears to be universal, in that all people desire to live in an environment that is fair (Lerner 1980). That said, the importance and strength of the motive is subject to individual variation. For example, Jost et al. (2003) demonstrated how the expression of this motive is most linked to needs for order and closure, and lower scores on measures of 'openness to experience', with these traits typically linked to factors such as a conservative-based personality. Crucially for our argument, these traits also tend to be more prevalent within highly religious communities than in general public samples (e.g. Brandt \& Reyna 2010; Saraglou 2002). Further, given the scale of recent media scandals about CSA within religious communities, it is perhaps reasonable to suggest that members of such communities feel under threat about the legitimacy and inherent morality of their institutions. As such, we argue that SJT offers one psychological framework for understanding why, under certain circumstances, members of religious organisations may suppress and not report incidents of alleged CSA.

In the only paper to directly examine responses to sexual offending using a system justification approach, Ståhl et al. (2010) presented two studies demonstrating that the system justification motivation contributes to enhanced attributions of blame being made 
about victims of rape. In the first of these studies, the authors found that modern sexism (operationalised as the view that women and men are essentially equal in contemporary society, and that attempts to advance gender equality further are futile) predicted rape victim blaming (operationalised as the belief that a victim of rape could have done more to prevent her victimisation, or was in some way responsible for it occurring). However, this effect was only found among male participants, with no such influence of modern sexism on victim judgements among females taking part in the study. This result can be interpreted as males attributing blame to the victim of rape in order to strengthen the view that the sexes are equal within society. That is, if they did not attribute this blame, it would implicitly assert that the offender (a male) did not treat the victim (a female) as an equal, which would be a threat to these participants' perception of equality between the genders. In the second study, Ståhl et al. (2010) reported that the use of stereotypes about women (such that they are caring and seductive) led to increased levels of victim blaming among female participants scoring high on modern sexism. Among males, however, there was no interaction between stereotype priming and modern sexism scores in relation to levels of rape victim blaming. Again, this result was consistent with a system justification approach to victim blaming, in that females (typically the victims of rape) can be primed into 'justifying the system' (i.e. engaging in rape victim blaming) under certain circumstances. Kay et al. (2005) referred to this process as victim derogation, and argued that people are often motivated to attribute blame to those at the bottom of the social ladder for their position in society in order to bolster a perception of fairness within the 'system', even if they are members of the derogated group.

We argue that the system justification motivation is high among religious individuals in relation to allegations of sexual abuse within their institutions. The 
perceived scale of clergy-perpetrated sexual abuse among wider society may lead to the perception among religious groups that their system is under threat. Consistent with SJT, we propose that it is this perceived threat that contributes to a propensity to 'close ranks' when allegations of CSA surface within these contexts. As such, we would expect that such a propensity could be primed among religious individuals. Experimentally, we would hypothesise that presenting a news story ostensibly about a case of clergyperpetrated CSA with system-threatening information embedded in this (e.g. suggestions that abuse is endemic within such institutions) would increase the likelihood that religious participants would (a) minimise the abusive nature of such interactions, (b) derogate or blame alleged victims, and (c) offer support to the alleged perpetrator. In contrast, the presentation of a news story with embedded information designed to alleviate perceptions of system threat could have the opposite effect, increasing the likelihood of the allegation being taken seriously and reported to the relevant authorities. In line with Minto et al.'s (2016) findings, we might expect some level of mediation by degree of religiosity in these outcomes. That is, those with a greater level of religiosity (or attachment to their particular institution) may demonstrate these effects to a greater degree, such is their attachment to the 'system' that is being justified.

If we are correct in our assertions, these findings could have profound implications for the ways in which we discuss the reporting of CSA in religious settings. Firstly, it may be possible to issue media outlets with guidance about how to maximise the potential for members of religious communities to report allegations of such abuses. Similarly, safeguarding officers and social workers operating directly within these communities may be able to use SJT principles (such as highlighting the threat posed to the 'system' by perpetrator actions, rather than by exposing abuses) in order to promote the reporting of 
alleged CSA 'on the ground'. It can be emphasised, for instance, that any effort to protect the institution instead of the victim will inevitably damage both. Ultimately, utilising a SJT approach in this area offers the potential to understand the psychological processes that underpin (non-)reporting of CSA in religious settings, and further to improve these practices moving forward.

\section{Moral Foundations Theory}

Aside from specific (and perhaps conscious) motivations to bolster and justify their social identity and worldview, members of religious institutions may also have deeper, perhaps non-conscious reasons for not reporting alleged cases of abuse within their communities. Harper \& Harris (2016) recently advanced the argument that our moral makeup may be in part responsible for the ways in which we respond to reported cases of sexual offending.

Moral foundations theory (MFT; Haidt \& Joseph 2004) asserts that human morality is a multifaceted phenomenon. MFT is based on three clear premises. First, we appear to take a dual-process approach to important or contentious decision making. Harper \& Harris (2016) called this process "feel first, rationalize later" (p. 5). That is, we have automatic emotional responses to certain stimuli, and then rationalise these responses through conscious elaboration. In this sense, we could conceptualise the degradation of CSA allegations within religious settings as rationalisations of an automatic negative emotional reaction to the perceived threat that the allegation poses to the institution. Second, morality is a multi-dimensional construct. Jonathon Haidt and his colleagues have systematically reviewed the literature pertaining to morality in the areas of cultural and evolutionary psychology (Haidt \& Graham 2007; Haidt \& Joseph 2004; Iyer et al. 
2012), and suggest that human morality is comprised of six 'moral foundations' (Table 1). The third premise of MFT is that the relative importance of each moral foundation differs within each individual, giving everybody a distinct and idiographic moral composition. These varying compositions have been linked to established political ideologies. For example, those who highly subscribe to issues about 'care' and 'fairness', but less so those linked to the other four foundations, tend to identify as politically liberal, while conservatives typically endorse all six foundations equally.

\section{[Insert Table 1 Here]}

We suggest that embedding the principles of MFT within communication and safeguarding training in religious settings has the potential to develop people's understanding of current reporting practices, and subsequently to improve such behaviours. Indeed, a recent study by Niemi \& Young (2016) found that higher levels of endorsement of the 'binding' foundations (i.e. authority, loyalty, and purity) increased victim blaming in cases of sexual and non-sexual crime. A logic first step in this endeavour to establish the religion-specific interaction between MFT principles and reporting behaviour would be to systematically examine the roles of each of the moral foundations in reporting practices. This could be conducted using survey methods incorporating Graham et al.'s (2011) Moral Foundations Questionnaire (MFQ). The MFQ is a validated self-report measure of respondents' endorsement of each moral foundation, and has been found to be predictive of political orientation/identification, as well as views about politically-controversial issues (e.g. Iyer et al. 2012; Koleva et al. 2012; Low \& Wui 2016). By administering such a measure when asking respondents about their views 
in relation to sexual abuse in religious institutions may help us to understand the deeper understanding of the moral basis for (non-)reporting of alleged CSA in these contexts. These data can then be used in order to frame training and other communication materials in an attempt to improve reporting practices (for an example of how framing arguments in accordance with MFT principles can be effective, see Day et al. 2014).

\section{Concluding Remarks}

In this article, we have systematically outlined why reporting practices in relation to alleged CSA in religious settings requires further investigation, and have highlighted two conceptual frameworks from social psychology that could help researchers in this endeavour. We argue that (non-)reporting practices in these settings have their genesis in deep-rooted psychological processes, and understanding these processes offers a potentially useful way to shape communication both within and outside of religious institutions in order to facilitate better reporting practices.

Further work is undoubtedly required in order to examine the empirical and practical validity of the arguments that we have advanced in this article. Naturally, there will also be other cultural variables that impact upon reporting practices (e.g., degree of religiosity, and attitudes and beliefs about sexuality) that also require some level of analysis in order to produce a holistic account about why members of religious groups may be reluctant to discuss allegations of CSA within their institutions. However, by examining these practices from a psychological perspective, we may be able to gain knowledge about these issues that improve communication styles, and ultimately prevent those who pose a risk to children from continuing to operate within such settings. 


\section{References}

Brackenridge C. H. 2001. Spoilsports: Understanding and Preventing Sexual Exploitation in sport. Routledge: London.

Brandt M. J. and Reyna C. 2010. The role of prejudice and the need for closure in religious fundamentalism. Personality and Social Psychology Bulletin 36: 715-725. DOI: 10.1177/0146167210366306.

Carr A. 2001. Understanding emotion and emotionality in a process of change. Journal of Organizational Change Management 14: 421-436. DOI: 10.1108/EUM0000000005873.

Children's Bureau. 2016. Penalties for Failure to Report and False Reporting of Child Abuse and Neglect. Children's Bureau: Washington, DC.

Cummins P., Scott D. and Scales B. 2012. Report of the Protecting Victoria's Vulnerable Children Inquiry. State of Victoria Government: Melbourne, Australia.

Day M. V. Fiske S. T., Downing E. L. and Trail T. E. 2014. Shifting liberal and conservative attitudes using moral foundations theory. Personality and Social Psychology Bulletin 40: 1559-1573. DOI: 10.1177/0146167214551152.

Graham J., Nosek B. A., Haidt, J., Iyer R., Koleva S. and Ditto P. H. 2011. Mapping the moral domain. Journal of Personality and Social Psychology 101: 366-385. DOI: $10.1037 / \mathrm{a} 002847$.

Haidt J. and Graham J. 2007. When morality opposes justice: Conservatives have moral intuitions that liberals may not recognize. Social Justice Research 20: 98-116. DOI: 10.1007/s11211-007-0034-Z.

Haidt J. and Joseph C. 2004. Intuitive ethics: How innately prepared intuitions generate culturally variable virtues. Daedalus, 133: 55-66. DOI: 10.1162/0011526042365555. 
Harper C. A. and Harris A. J. 2016. Applying moral foundations theory to understanding public views of sexual offending. Journal of Sexual Aggression. DOI: $10.1080 / 13552600.2016 .1217086$.

HM Government. 2015. Working Together to Safeguard Children. HM Government: London, UK.

Iyer R., Koleva S. P., Graham J., Ditto P. H. and Haidt J. 2012. Understanding libertarian morality: The psychological dispositions of self-identified libertarians. PlosONE 7: e42366. DOI: 10.1371/journal.pone.0042366.

John Jay College. 2004. The Nature and Scope of Sexual Abuse of Minors by Catholic Priests and Deacons in the United States, 1950-2002. United States Conference of Catholic Bishops (USCCB): Washington, DC.

John Jay College. 2006. The Nature and Scope of Sexual Abuse of Minors by Catholic Priests and Deacons in the United States, 1950-2002: Supplementary Data Analysis. USCCB: Washington, DC.

Jost J. T. Banaji M. R. and Nosek B. A. 2004. A decade of system justification theory: Accumulated evidence of conscious and unconscious bolstering of the status quo. Political Psychology 25: 881-919. DOI: 10.1111/j.1467-9221.2004.00402.x.

Jost, J. T., Blount, S., Pfeffer, J., and Hunyady, G. 2003. Fair market ideology: Its cognitive-motivational underpinnings. In: Research in organizational behavior: An annual series of analytical essays and critical reviews (vol. 25). Staw B. M. \& Kramer R. M. (ed.), Elsevier Science Ltd: Oxford, UK; pp. 53-91.

Jost, J. T. and Hunyady O. 2005. Antecedents and consequences of system-justifying ideologies. Current Directions in Psychological Science 14: 260-265. DOI: 10.1111/j.0963-7214.2005.00377.x. 
Jost J. T. and Thompson E. P. 2000. Group-based dominance and opposition to equality as independent predictors of self-esteem, ethnocentrism, and social policy attitudes among African Americans and European Americans. Journal of Experimental Social Psychology 36: 209-232. DOI: 10.1006/jesp.1999.1403.

Kay A. C., Jost J. T., Mandisoza A. N., Sherman S. J., Petrocelli J. V. and Johnson A. L. 2007. Panglossian ideology in the service of system justification: How complimentary stereotypes help us to rationalize inequality. Advances in Experimental Social Psychology 37: 305-358. DOI: 10.1016/S0065-2601(06)39006-5.

Kay A. C., Jost J. T. and Young, S. 2005. Victim derogation and victim enhancement as alternate routes to system justification. Psychological Science 16: 240-246. DOI: 10.1111/j.0956-7976.2005.00810.x.

Keenan M. 2012. Child Sexual Abuse and the Catholic Church: Gender, Power, and Organizational Culture. Oxford University Press: Oxford, UK.

Koleva S., Graham J., Ditto P, Iyer R. and Haidt J. 2012. Tracing the threads: How five moral concerns (especially purity) help explain culture war attitudes. Journal of Research in Personality 46: 184-194. DOI: 10.1016/j.jrp.2012.01.006.

Lerner M. J. 1980. The Belief in a Just World: A Fundamental Delusion. Plenum Books: New York, NY.

Levi B. H., Brown G. and Erb C. 2006. Reasonable suspicion: A pilot study of pediatric residents. Child Abuse \& Neglect 30: 345-356. DOI: 10.1016/j.chiabu.2005.05.004.

Lonne B. and Parton N. 2014. Portrayals of child abuse scandals in the media in Australia and England: impacts on practice, policy, and systems: most media coverage distorts the public understandings of the nature of child maltreatment. Child Abuse \& Neglect 38: 822-836. DOI: 10.1016/j.chiabu.2014.04.020. 
Low M. and Wui M. G. L. 2016. Moral foundations and attitudes towards the poor. Current Psychology 35: 650-656. DOI:10.1007/s12144-015-9333-y.

Mathews B. and Kenny M. C. 2008. Mandatory reporting legislation in the United States, Canada, and Australia: A cross-jurisdictional review of key features, differences, and issues. Child Maltreatment 13: 50-63. DOI: 10.1177/1077559507310613.

McLoone-Richards C. 2012. Say nothing! How pathology within Catholicism created and sustained the institutional abuse of children in 20th century Ireland. Child Abuse Review 21: 394-404. doi:10.1002/car.2209.

Minto K., Hornsey M. J., Gillespie N., Healy K. and Jetten, J. 2016. A social identity approach to understanding responses to child sexual abuse allegations. PLOS ONE 11: e0153205. DOI:10.1371/journal.pone.0153205.

Murphy F. D., Buckley H. and Joyce L. 2005. The Ferns Report, presented by the Ferns Inquiry to the Minister for Health and Children. Stationary Office: Dublin, Ireland.

Murphy J. Y., Mangan I. and O'Neill H. 2009. Report of the Commission of Investigationreport into the Catholic Archdiocese of Dublin. Irish Department of Justice and Equality: Dublin, Ireland.

Niemi L. and Young L. 2016. When and why we see victims as responsible: The impact of ideology on attitudes toward victims. Personality and Social Psychology Bulletin 42: 1227-1242. DOI: $10.1177 / 0146167216653933$.

NSPCC. 2014. Exploring the Case for Mandatory Reporting: A Summary of a Roundtable Hosted by the NSPCC. NSPCC: London, UK.

Parliament of Victoria. 2013. Betrayal of Trust: Inquiry into the Handling of Child Abuse by Religious and Other Non-Government Organisations. Parliament of Victoria: Melbourne, Australia. 
Reilly T. F. 2003. The Sexual Abuse of Children in the Roman Catholic Archdiocese of Boston. Office of the Attorney General Commonwealth of Massachusetts: Boston, MA.

Ryan S. 2009. Commission to Inquire into Child Abuse. Government of Ireland: Dublin, Ireland.

Saraglou V. 2002. Beyond dogmatism: The need for closure as related to religion. Mental Health, Religion \& Culture 5: 183-194. DOI: 10.1080/13674670210144130.

Scheper-Hughes N. and Devine J. 2003. Priestly celibacy and child sexual abuse. Sexualities 6:15-40. DOI: 10.1177/1363460703006001003.

Smith M. C. 2010. Early childhood educators: Perspectives on maltreatment and mandated reporting. Children and Youth Services Review 32: 20-27. DOI: 10.1016/j.childyouth.2009.06.011.

Spröber N., Schneider T., Rassenhofer M., Seitz A., Liebhardt H., König L. and Fegert J. M. 2014. Child sexual abuse in religiously affiliated and secular institutions: a retrospective descriptive analysis of data provided by victims in a governmentsponsored reappraisal program in Germany. BMC Public Health 14: 1-12. DOI: 10.1186/1471-2458-14-282.

Ståhl T., Eek D. and Kazemi, A. 2010. Rape victim blaming as system justification: The role of gender and activation of complementary stereotypes. Social Justice Research 23: 239-258. DOI: 10.1007/s11211-010-0117-0.

Stoltenborgh M., van Ijzendoorn, M. H., Euser, E. M. and Bakermans-Krananburg, M. J. 2011. A global perspective on child sexual abuse: Meta-analysis of prevalence around the world. Child Maltreatment 16: 79-101. DOI: 10.1177/1077559511403920. 
Terry K. J., Smith M. L., Schuth K., Kelly J. R., Vollman B. and Massey C. 2011. The Causes and Context of Sexual Abuse of Minors by Catholic Priests in the United States, 1950-2010. USCCB: Washington, DC. 
Table 1: The foundations of human morality, according to MFT

\begin{tabular}{|c|c|c|}
\hline Moral foundation & Description & Typical moral behaviours \\
\hline Care & $\begin{array}{l}\text { We are biologically designed } \\
\text { to care for our young, and } \\
\text { those who are unable to care } \\
\text { for themselves }\end{array}$ & $\begin{array}{l}\text { 1. Protection and } \\
\text { compassion for children } \\
\text { and those unable to care } \\
\text { for themselves }\end{array}$ \\
\hline Fairness & $\begin{array}{l}\text { We are driven to gain social } \\
\text { resources through reciprocal } \\
\text { altruism and mutual co- } \\
\text { operation. Rewards and } \\
\text { punishments are given out } \\
\text { proportionately. }\end{array}$ & $\begin{array}{l}\text { 1. Support for the fair } \\
\text { distribution of social } \\
\text { resources, based upon } \\
\text { shared social values } \\
\text { 2. Anger towards those who } \\
\text { gain resources through } \\
\text { unfair or unjustified } \\
\text { means }\end{array}$ \\
\hline Loyalty & $\begin{array}{l}\text { Historically, we needed to } \\
\text { form coalitions with kin in } \\
\text { order to protect our own tribes } \\
\text { from enemies }\end{array}$ & $\begin{array}{l}\text { 1. Patriotism and pride in } \\
\text { one's group and national } \\
\text { identity } \\
\text { 2. Development of strong } \\
\text { relationships based on } \\
\text { homogeneous ideologies }\end{array}$ \\
\hline Authority & $\begin{array}{l}\text { We require organised social } \\
\text { structures in order to operate } \\
\text { effectively. These are } \\
\text { typically organised as } \\
\text { hierarchies }\end{array}$ & $\begin{array}{l}\text { 1. Deferment to agreed } \\
\text { social hierarchies } \\
\text { 2. Respect for social leaders }\end{array}$ \\
\hline Sanctity & $\begin{array}{l}\text { We are driven to avoid } \\
\text { physical and behavioural } \\
\text { pathogens that threaten the } \\
\text { wellbeing of our bodies or } \\
\text { social norms }\end{array}$ & $\begin{array}{l}\text { 1. A drive to avoid exposure } \\
\text { to disease } \\
\text { 2. Expressed disgust at } \\
\text { socially-taboo ideas }\end{array}$ \\
\hline
\end{tabular}


Liberty

We are driven towards self-

1. Desire for freedom from

determination and freedom

Government interference

from control

in personal and financial

affairs 